\title{
Seven Cold Cities: the Milonga of Vitor Ramil
}

Bryan McCann ${ }^{1}$

For over two decades, composer and performer Vitor Ramil has patiently explored the possibilities of milonga to evoke an imagined musical and poetic landscape of the pampas and cities of southern Brazil. The result is a singular body of work, one that eschews pretension to represent the nation in favor of standing firmly on a regional terrain that is also transnational, shared with Uruguay and Argentina. At the same time, Ramil draws deeply on the achievements and sensibility of música popular brasileira or MPB. Ramil's milonga is structurally the same as that of any number of gaúcho composers, but poetically it is all his own, immediately recognizable. The disciplined syncopation of traditional milonga is a key component of this work, a springboard for Ramil's subtly buoyant music.

Ramil devoted himself to milonga after a decade of innovative work in MPB, and like all the best MPB composers he is keenly self-aware. He has expressed the guiding tenets of his approach more gracefully than any critic could hope to do in his music and in his other writings, as well as in the rare interviews he concedes (cf: Wrege Rassier, 2004). His "Milonga das Sete Cidades" is a quiet manifesto, clearly declaring his principles. The song imagines an archipelago of seven cities spread across the pampas, each one embodying a characteristic necessary to Ramil's understanding of milonga. The cities are named Rigor, Profundidade, Clareza, Concisão, Pureza, Leveza and Melancolia (Rigor, Profundity, Clarity, Concision, Purity, Lightness and Melancholy), and each

\footnotetext{
${ }^{1}$ Georgetown University, USA.

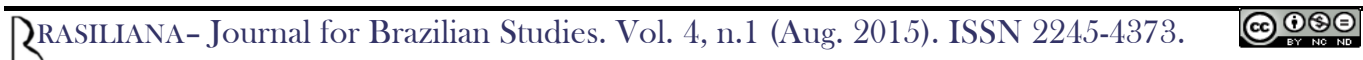


makes its own salient contribution. Combined, they form the foundation for Ramil's balanced, inquisitive milonga.

Leveza is the imagined city-and the quality - most clearly linked to rhythmic syncopation. Like many Afro-Atlantic genres, the milonga has a regular, pulsing syncopation, created in this case by a 123-123-12 rhythmic cell, explained in more detail below. It is that syncopation that confers leveza-lightness or buoyancy-on Ramil's compositions, balancing the melancholy of his lyrics and the rigor of his vocal timbre. In “Milonga das Sete Cidades," Ramil sings, “Em Leveza o céu se abriu,” suggesting a parting of the clouds. This article explores that leveza in the context of Ramil's milonga and the composer's larger body of work. The argument is that, by drawing on a musical form that is both deeply traditional and characterized by rhythmic syncopation, Ramil finds the freedom to create a powerful body of work, deeply rooted in regional sensibility but marked by artistic individuality.

\section{Ramil's Early Career}

Ramil was born in 1962 in Pelotas, Brazil's southernmost major city (if that adjective applies to a city of some 300,000 inhabitants, one that reached its economic peak as a center for dried-beef export in the mid nineteenth-century). Pelotas is a two-hour drive from the Uruguayan border, and in cultural sensibility it is more closely linked to Montevideo and Buenos Aires than to Rio de Janeiro. Ramil grew up immersed in the blend of Spanish and Portuguese, liberally sprinkled with distinctly local terms, that characterizes the language of the border region.

He was the youngest of six siblings in a deeply musical family. His childhood memories include hearing his father sing tango, his mother the Brazilian melodramatic 
material of the 1930s and his older brothers playing Beatles records. All would help shape his musical consciousness.

By the time Ramil was a teenager, his older brothers Kleiton and Kledir were successful performers, fronting a band known as Almôndegas, one that honed a blend of Beatles-influenced pop with local instrumentation. By the end of the 1970s, Kleiton and Kledir had left Almôndegas and embarked on their own career. In the early 1980s, they became the surprise sensation of Brazilian popular music. Their success challenged the restrictions of an industry heavily concentrated in Rio de Janeiro and São Paulo. Hits like "Deu Pra Ti" were rich in the local slang of the Brazilian south and celebrated Porto Alegre as a vibrant metropolis. Others, like "Maria Fumaça" and "Desafio" updated folkloric forms of the Brazilian south, gently lampooning and borrowing from traditional genres.

Even Kleiton and Kledir, however, needed to leave Rio Grande do Sul to reach national prominence, and they spent much of the 1980s based in Rio de Janeiro. They played a decisive role in the early career of their younger brother, encouraging his early efforts as a composer and performer and introducing him to key figures in the industry. Less directly, they modeled for him two possible career paths in popular music. The first was trying to build a career in Rio Grande do Sul composing songs that drew on both local tradition and global popular music. The other consisted of packing up and moving to Rio or São Paulo to try to make it in the heart of the Brazilian entertainment industry.

In the short term, only the second path appeared viable: like most global styles of the mid-1980s, the most prominent Brazilian styles were synthesizer-heavy, slick studio productions. Local color was out, global synth was in. Ramil packed his bags and moved to Rio.

For a young songwriter from the Brazilian periphery, he was remarkably successful. By 1985, his songs had been recorded by the famed Brazilian singers Gal 
Costa and Zizi Possi, as well as the Argentine Mercedes Sosa. And he had recorded two albums of his own, Estrela, Estrela in 1981 and A Paixão de V. Segundo Ele Próprio in 1984. The first was a document of impassioned youth, the second an experimental sound collage. The widely varying sounds and instrumentation of the second album suggested a restless, unresolved artistic personality, while the prominence of synthesizers marked the work as a product of the mid-1980s-one where poetic tone often clashed with the instrumentation. Among its most fully-realized selections were two milongas, "Semeadura" and "Milonga de Manuel Flores," the first an evocation of the gaúcho pampas, with lyrics blending Spanish and Portuguese, the second a Portuguese translation of a poem by the Argentine writer Jorge Luís Borges. These songs hinted at the possibility of a more extensive investigation of southern Brazilian regional sounds. A third milonga on the album, "Fragmento de Milonga," appeared only in deliberately partial form, thirty seconds of traditional milonga washed out by a return to synthesized studio sounds. "Fragmento de Milonga" suggested that any sustained exploration of the form would have to wait.

With the release of Tango, in 1987, Ramil reached a new level of polish. Album title notwithstanding, the material was not tango but MPB of the highest caliber, each song carefully crafted, open to multiple interpretations. The musicians were among the best jazzmen in Brazil, including Nico Assumpção on bass, Márcio Montarroyos on trumpet, Hélio Delmiro on electric guitar and Leo Gandelman on sax. The songs on Tango remain among Ramil's best-known, including the effusive, declamatory "Loucos de Cara," with Ramil's lyrics written for a composition by his brother Kleiton.

Tango's strongest touch of southern Brazilian regionalism, oddly, comes on a Bob Dylan cover-Ramil's "Joquim" puts his own lyrics to "Joey," the Dylan-Jacques Levy classic. Ramil leaves behind Dylan's tale of mafioso gangland slaughter in order to retell the life of Joaquim Fonseca, a visionary inventor from Ramil's hometown of Pelotas. In 
the early 1940s, when Brazil barely had an auto industry to speak of, Fonseca designed and built several airplanes and planned to create an airplane factory in Pelotas. The Brazilian government blocked his plans. "Joquim" narrates this history of brilliant imagination stymied by bureaucratic obstruction.

Tango seemed to take the carioca phase of Ramil's career as far as it could go. The album was a critical success but not a commercial one. Its musicianship was beyond reproach but at the same time the album's cosmopolitan gloss was frustratingly impersonal. It could equally well have been the sound of an Ivan Lins album, or for that matter a Joni Mitchell album, conveying the assured sophistication of top jazz session players without a strong individual stamp. Ramil began to wonder why he was grinding away in Copacabana while his deepest sensibility seemed to pull him back home.

\section{Estética do Frio}

Few popular composers have recounted their own epiphanies in terms as eloquent and reflective as Ramil. In 2003, he delivered an invited lecture in Geneva, Switzerland, entitled "L'esthétique du froid," subsequently translated, revised and published as "A Estética do Frio" (Ramil, 2006)². In the lecture, Ramil recalled the moment he decided to leave Rio de Janeiro. On a June morning sometime in the early 1990s, he was drinking chimarrão, or hot mate, in his Copacabana apartment, a practice rooted in the traditions of the Rio de la Plata basin, out of step with the climate in Rio, sweltering even in midwinter. As he sipped, Ramil watched a televised newscast about a micareta in Northeastern Brazil, a music festival characterized by sound trucks blaring catchy, upbeat tropical Brazilian pop to throngs of sweaty dancers. The newscast then switched

\footnotetext{
${ }^{2}$ The ability to write and lecture in French is not a skill-set commonly found among Brazilian popular composers.
} 
abruptly to coverage of a cold snap in the far south, showing footage of fields covered in ice, and children scratching their names in the frost that covered their windows. The news anchor described the micareta as a characteristically Brazilian celebration but described the frigid weather in the south as something typical of a European climate, as if the south were a different country.

Ramil, in his retelling, felt a strong kinship with the scenes of the frost and ice but felt completely alienated from the tropical exuberance of the micareta and stifled by the heat in his Copacabana apartment. He wanted nothing so much as to be on a plane to Porto Alegre. Thus began his quest to work within a conscious aesthetics of the cold, one true to his gaúcho childhood and to his sense of interiority and reflection. In pondering the guiding principles of this aesthetics of cold, Ramil arrived at the qualities of concision, rigor, profundity, purity, clarity, lightness and melancholy. These became the seven cities of his imaginary pampas, the reference points for the travels of this solitary troubador.

Ramil would probably be the first to note that the aesthetics of cold is an abstract ideal, often at odds with real life in the Brazilian south (Cf: Wrege Rassier, 2008). ${ }^{3}$ Pelotas is not Patagonia. Porto Alegre is oppressively hot and humid from December to March, its climate similar to Richmond, Virginia. In the summertime, only the aesthetics are cold in Rio Grande do Sul. How, then, to prevent the aesthetics of cold from becoming as artificial as the synth-pop of Rio studios? The answer had the inevitability of the truly elegant solution: milonga.

\section{Milonga Campera}

${ }^{3}$. Wrege Rassier offers a lucid analysis of Ramil's estética do frio and its manifestation in the album Ramilonga. 
The milonga cohered as a distinct musical genre through the same process of AfroAtlantic exchange, influence and variation that yielded rumba, samba, tango and other celebrated forms. As in many of these cases, the word itself was thrown around in imprecise ways in the nineteenth century, then came to designate a more consistent set of musical practices around the end of that century and the beginning of the next. The proliferation of sheet music, piano rolls, early recordings and finally radio all facilitated this process of consolidation and differentiation of genres.

In the case of milonga, this process took place primarily in Buenos Aires and Montevideo. The milonga in these urban centers evolved quickly into the iconic Argentine tango. But this urban milonga had a rural cousin, milonga campera, one that did not change so quickly, and that spread throughout the grasslands of the Rio de la Plata basin, transcending linguistic and national borders.

In all cases, the rhythm was the most important defining characteristic. The basic rhythmic cell of milonga covers two bars of 2/4 time (two quarter notes per bar), divided into eight sixteenth-notes. The milonga breaks these eight sixteenth-notes into three uneven parts, which can be counted out as 123-123-12. The "1" in each part is stressed, while the " 2 " and " 3 " are unstressed. This means that the strong, " 1 " notes fall on the first, fourth and seventh of the eight sixteenth-notes. The other notes are unstressed, either played more softly or not played at all. That two-bar rhythmic cell is repeated throughout, the foundation of all milonga.

This is considered a syncopated rhythm, because the stressed notes fall unevenly and do not fall on the notes where one would expect them to in the Western, classical tradition. A "straight" 2/4 would stress the first and fifth notes in a group of eight 
sixteenth notes. Because the milonga stresses one, four and seven, it cuts against these classical prescriptions. ${ }^{4}$

At the same time, because this basic rhythmic cell is repeated throughout, it does not come as a surprise. It thus falls into the category of expected or structural syncopation. In terms of Western, classical music theory, this is a contradiction in terms. But it is the foundation of Afro-Atlantic music, and is the open secret of that music's allure. Given the prominence of Afro-Atlantic rhythmic forms in global popular music, nearly everyone is familiar with these rhythms, at least unconsciously. Our ears are accustomed to both the Western, classical structure with its preference for the "straight" rhythm and to the Afro-Atlantic rhythmic cell with its uneven divisions. It is the tension between these two expectations that seems to drive the music forward. In the case of milonga, the pattern of uneven stress gives the rhythm momentum and, yes, leveza.

It should be noted that the same 123-123-12 cell serves as the basis for tango, maxixe and habanera. (Cf: Miller, 2011) What else goes into the music to make it the milonga campera characteristic of the pampas? Like most Latin American genres ostensibly defined by rhythm, there are several conventions of instrumentation, melody, harmony, compositional structure and lyrical subject matter that help to define the music as milonga. These are not fundamental in the same way the rhythm is-each can be altered or subtracted without removing the song from the category of milonga. But they help to situate the music within the tradition.

Milonga of the pampas is a storytelling genre, not a dance genre. The lyrics portray life in the grasslands, usually in a way that celebrates rugged cowboys and their independence. There is a great deal of red meat in traditional milonga campera, in its

\footnotetext{
${ }^{4}$ For further discussion of patterns of syncopation in Brazilian popular music, see Richard Miller, "African Rhythms in Brazilian Popular Music: Tango Brasileiro, Maxixe and Choro,” Luso Brazilian Review 48:1 (2011): 6-35.
} 
Argentine, Uruguayan and particularly its Rio Grandense (from Rio Grande do Sul) varieties.

Milonga campera is usually in a minor key, or modulates between a minor key and its relative major. Like most popular song, milonga generally alternates verses and chorus. The verses are usually in poetic stanzas ranging from four to eight lines in length, using a variety of rhyme schemes, most commonly abba and abbccb. The form of these poetic stanzas helps to place the milonga campera in the context of IberoAmerican cowboy song, in kinship with northeastern Brazilian baião, Cuban son and Colombian vallenato, among other genres. Milonga campera can be subdivided into narrower categories based on the differentiation between these poetic stanzas, but as Ramil works in various poetic forms, that is largely irrelevant here.

Milonga instrumentation privileges guitar and bandoneon or gaita-de-ponto, both of these latter instruments among the smaller members of the accordion family. And traditional milonga of Rio Grande do Sul usually features a bombastic vocal style.

\section{Ramil's variations}

Vitor Ramil's milonga necessarily relies on the genre's basic rhythm cell-this is both the required element of the genre and the key to Ramil's leveza. He engages with each of the remaining characteristics of traditional milonga selectively, drawing on tradition without being confined by it (Cf: Sosa, 2010).

Ramil is a consummate storyteller but his perspective, tone and setting differ markedly from traditional milonga. There is less red meat and more quiet observation in Ramil's approach. His lyrics as often describe the city as the country. The title of his 1997 composition "Ramilonga" combines his last name with the name of the genre, signaling his claim both to make the milonga his own and to express himself fully through the 
genre. The lyrics describe a rainy afternoon in Porto Alegre. The narrator walks through the city, describes his fleeting impressions and intones, "nunca mais, nunca mais." The song continues, “O tango dos guarda-chuvas na Praça Quinze/confere elegância ao passo da multidão." It is unlikely that any previous milonga composer mentioned umbrellas, much less described their elegant dance through crowded city streets on a rainy afternoon.

Like traditional milonga, Ramil's compositions are usually minor-key or modulate between a minor key and its relative major. But Ramil often composes in keys rarely used in popular song, such as F minor. And he plays his guitar in a way that shifts the harmony subtly from one chord to another, drawing more on MPB guitar and its bossa nova precedents than on the relatively straightforward strummed chords of traditional milonga. The result is a harmony that is more eerie than melancholy. Melodically, as well, Ramil is more tolerant of dissonance than most traditional milongueiros. He draws frequently on the dominant seventh, and occasionally on the flat third, notes that bring to the surface the deep Arabic influence on Ibero-American cowboy music.

Ramil draws on the poetic conventions of traditional milonga, using its rhyme schemes, but brings his own unusual perspective to their execution. He does not disdain cowboy poetry, but he draws on a more varied anthology. His 2011 album Delibab, for example, includes twelve Ramil compositions written as musical settings for the poetry of Jorge Luis Borges and the Rio Grandense cowboy poet João Cunha Vargas. Ramil works specifically with a body of Borges poems initially published as "milongas," albeit without music. Borges's "milonga" poems are set largely on the urban fringes of Buenos Aires and Montevideo, a shadow world of gambling, knife fights and blood feuds. In contrast to A Paixão de V. Segundo Ele Próprio, where Ramil translated Borges's “Milonga 
de Manuel Flores" into Portuguese, on Delibab he sings Borges's words in the original Spanish (Cf: Lima, 2012).

Each Borges selection is alternated with a musical setting of one of Cunha Vargas's poems, the epitome of traditional gaúcho cowboy poetry-the smell of cattle seems to emanate from Cunha Vargas's words. Delibab thus deliberately alternates Spanish and Portuguese, Argentina and Rio Grande do Sul, city and country, alley fights and corrals. Ramil's compositional style and delivery remain consistent throughout-subtly inventive, thoughtful, sincere. The undertaking itself is Borgesian, a subtle game of mirrors and adopted identities. In his musical settings of Borges and Cunha Vargas, and in their presentation on the album, Ramil suggests that these are the two necessary halves of milonga.

Ramil's instrumentation also departs from traditional milonga. He rarely incorporates bandoneon or gaita-de-ponto (although it would not be surprising to hear him draw on these instruments). More strikingly, he occasionally incorporates instruments from outside the tradition. The Ramilonga album of 1997, for example, used stand-up acoustic bass, tabla and sitar, instruments that accentuated the otherworldly quality of Ramil's work.

\section{Ramil v The Traditionalists}

Perhaps the most obvious difference between Ramil's milonga performance and traditional milonga is his vocal delivery. In contrast to the melodramatic style of traditional milongueiros, Ramil sings in an intimate, conversational tone, varying from the hushed assurance of a poetry reading to the carefully-measured emotion of a cabaret crooner. This draws attention to the lyrics themselves and also serves to separate him clearly from the traditionalists. 
Ramil's aesthetics of cold explicitly reacts to the restrictions and prejudices of the mainstream Brazilian music industry and its preference for tropical pop in various forms. More subtly, however, Ramil takes pains to avoid being pulled into the camp of the gaúcho traditionalists, a tribe which polices its membership with the fervor of those convinced they are protecting the sacred against the depredations of the profane.

Gaúcho traditionalism is a multi-disciplinary cultural movement, with specific prescriptions not only for music, but for dress, cuisine, dance and poetry. The movement emerged in its modern form in the 1940s, partly in reaction to political centralization and its perceived erosion of regional difference, partly in reaction to the urbanization and globalization of modern life. The self-styled gaúcho traditionalists founded Centros de Tradições Gaúchas, or CTGs, throughout the state of Rio Grande do Sul, eventually spreading to other states and internationally. The CTGs sought (and continue to seek) to preserve a largely-imagined golden past of gaúcho rural culture and to cultivate the practice of its forms among younger generations (Cf: Oliven, 1992).

By the 1960s, the CTGs had already become poles for the articulation of an embittered sense of gaúcho difference, often accompanied by calls for secession of Rio Grande do Sul from the union. As their political inflections became more shrill, their cultural restrictions became more severe. By the 1970s, a breakaway faction describing themselves as "nativists" rejected the narrow provincialism of the "traditionalists," insisting that one could preserve gaúcho music just as effectively when wearing blue jeans as when wearing bombachas, the traditional loose trousers of the gaúcho cowboy. The traditionalists were having none of it, and continued to insist on bombachas. The resulting feud remains unsettled (Cf: Oliven 1992).

When Ramil devoted himself to milonga in the 1990s, he risked getting pulled into this pointless conflict. He sensibly avoided this by continuing to position himself as a cosmopolitan performer. He is neither traditionalist nor nativist. He draws on the 
tradition and deliberately transforms it. In "A Estética do Frío," he explicitly cautions that the aesthetic is not normative. Concision, purity, profundity, clarity, rigor, lightness and melancholy are principles, not rules. Beyond the rhythm itself, there are no fixed rules to Ramil's milonga.

Ramil does not perform at the CTGs. It is difficult to imagine that he would be invited, and equally difficult to imagine that he would accept. He also does not usually perform in nightclubs or bars. He performs in theaters, before a seated, attentive audience, in conditions where he has control over lighting, sound, pace and duration of the spectacle. Everything about his approach indicates that his music is meant for serious listening, and he chooses to perform in conditions which facilitate that that kind of listening.

Although Ramil's wardrobe appears casual, everything else about his performance style is so carefully curated that one must infer that his clothing is chosen with equal care. He tends to perform in trousers and a sweater-invoking the aesthetic of cold, even in a warm theater-or in a buttoned shirt, usually one with vertical stripes accentuating his own slender frame. His long face and soulful eyes heighten the effect. His bearing and appearance call to mind a saint painted by El Greco. This is selfconsciously art milonga, not traditionalist milonga.

\section{Voyages of a New Milongueiro}

Following the epiphany that led to the articulation of his aesthetics of cold, Ramil recorded $\grave{A}$ Beça in 1996, the first attempt to put that aesthetics into practice. $\grave{A}$ Beça reached towards but did not fully realize those ambitions. Like Tango, it yielded songs that remain favorites among Ramil's devoted fans, but attracted little attention beyond that group. Ramilonga, the following year, was a breakthrough, a perfect synthesis of 
inspiration, principle and execution. Its "Milonga das Sete Cidades" was the lucid songmanifesto of Ramil's aestetics, a prelude and companion piece for the 2003 Geneva lecture. And the title track was the individualized enactment of that manifesto, fulfilling its promise to make milonga the vehicle for a self-expression that would be simultaneously deeply-rooted in regional culture and capable of the most nuanced poetic expression.

Following Ramilonga, Ramil wisely branched out. To limit himself to composing and performing only milonga would have been a self-defeating restriction for a composer who had already written successfully in a number of rhythms. For Tambong, his next album, he worked in a variety of styles, in a deliberately avant-garde but still accessible approach that might be termed Latin art rock. He recorded the album in Buenos Aires, with Argentine and Uruguayan, as well as Brazilian musicians, and recorded two versions of each song, one in Portuguese and the other in Spanish. This was not only a means to give a different inflection to the music, but the first step in the deliberate construction of a transnational circuit of performers and fans, linking Porto Alegre, Pelotas, Montevideo and Buenos Aires.

Uruguayan composer Jorge Drexler, and Argentine-Alaskan composer Kevin Johansen joined Ramil in this enterprise. Drexler's music has much in common with Ramil's aesthetics of cold, albeit with less explicit grounding in regional culture. Indeed, Drexler draws more deeply on bossa nova than does Ramil, while singing in Spanish. Johansen, in contrast, has more in common with the Brazilian tropicalists in his musical and performance style, favoring a more exuberant and jarring combination of local and global elements, leaving it to his audience to reconcile them. Johansen sings in both Spanish and English, often in the same song, heightening this effect of imperfectly assimilated elements. But all three performers targeted the same audience of educated cosmopolitans in the transnational Rio de la Plata basin, frustrated with the geographic 
and musical limitations of the mainstream music industry. Their loose collaboration helped to draw critical and audience attention to their fledgling circuit. Other composers and performers have since made common cause with these three pioneers, helping to realize Ramil's dream of a transnational platense circuit.

At the same time, Ramil by no means shut the door on his carioca friends. In 2007, he recorded Satolep Sambatown with the pioneering percussionist Marcos Suzano, of Rio. The album's title pairs the backwards-spelling of Pelotas (a conceit Ramil often uses when writing about his hometown) with Sambatown, the title of Suzano's first solo album, from 1996. Ramil and Suzano are the only musicians on the album, but it is as sonically rich as anything produced by a full band, largely because of Suzano's bottomless bag of percussion tricks and multilayered effects. It is one of Ramil's best albums, and one of the best MPB albums of the decade (Cf: Moehn, 2009).

In 2010, Ramil returned to milonga with the stunning Delibab. In contrast to Ramilonga, on Delibab Ramil strips down the instrumentation to a bare minimum. There is no Indian percussion, no stand-up bass. The only instruments are Ramil's steel-string guitar and the nylon-string guitar of the Argentine Carlos Moscardini, who ornaments Ramil's vocals with runs that are adept but never flashy. As with Tambong, Ramil made the album in Buenos Aires, in a gorgeously realized intimate recording. This intimacy and minimal instrumentation brings the leveza of the milonga rhythm to the surface. The twelve milongas on Delibab are deep in the syncopated groove, offsetting the melancholy of Borges's poems and the equine concerns of Cunha Vargas's.

Following this milonga masterpiece, Ramil once again stepped back, and looked to other rhythms. Foi No Mês Que Vem, of 2013, is a selective retrospective of Ramil's career to date, a double-album of 32 songs. Ramil sought crowd funding for the recording and distribution, and allowed fans to vote for the songs to be included. As in Delibab, the instrumentation is minimal, although Ramil makes room for distinguished 
guests, including Ney Matogrosso, Milton Nascimento and Fito Paez, as well as old partners like Marcos Suzano, Carlos Moscardini and Jorge Drexler. Like Satolep Sambatown, Foi No Mes Que Vem demonstrates that Ramil remains a powerful MPB composer and performer.

Meanwhile, not content with re-centering South American popular music, Ramil has published two novels, Pequod (1999) and Satolep (2008), as well as an allegorical fable, A Primavera da Pontuação (2014). These diverse enteprises show that while milonga has helped Ramil attain the full range and extent of that power, he could never limit himself to milongueiro (Cf: Wrege Rassier, 2008a).

\section{Conclusion}

What comes next for a fifty-something popular composer with over thirty years of career and several stylistic evolutions behind him? It would not be surprising if Ramil were to dedicate more of his attention to the written word, and to slow down the release of new music. On the other hand, the release of Foi No Mês Que Vem in the midst of a fertile period of production recalls the choice of Bob Dylan, one of Ramil's most consistent sources of inspiration, to release the retrospective collection Biograph in 1984. Dylan has continued to release new music for another three decades. Ramil is clearly not losing any of his creative power, and may choose a similar course.

Milonga may or may not turn out to be Ramil's preferred mode of expression in the future. It will surely remain a valuable resource. And the milongas he has already composed and recorded will stand as eloquent testaments to the possibilities of the genre. As Ramil put it in "Milonga das Sete Cidades," "A voz de um milongueiro não morre/ não vai embora em nuvem que passa/ sete cidades frias são sua morada." The leveza born of syncopation-or the syncopation born of leveza-is only one of the 
guiding principles of this milonga. But it is the one most decisive in elevating the enterprise from exercise to inspiration, and in making the music move.

\section{Vitor Ramil Discography:}

1981, Estrela, Estrela

1983, A Paixão de V. Segundo Ele Próprio

1987, Tango

1995, À Beça

1997, Ramilonga

2000, Tambong

2004, Longes

2007, Satolep Sambatown

2010, Delibab

2013, Foi No Mês Que Vem

\section{Bibliography:}

Agostini, Agostinho Luís. O pampa na cidade: o imaginário social da música popular gaúcha. (MA thesis, Universidade de Caxias do Sul, 2005).

Bozzetti, Roberto. Noite de São João: um poema de Caeiro e duas canções, de Vitor Ramil e Fred Martins. Revista Brasileira de Estudos da Canção. 2 (2012), accessed 22\08\15, http://www.rbec.ect.ufrn.br/Noite_de_São_João_um_poema_de_Caeiro_e_duas_canções

Lima, Gabriel Veppo de. Um Mango e un Cuchillo en el norte : João da Cunha Vargas e Jorge Luís Borges em Délibáb de Vitor Ramil. Paper presented at the VIII Congreso Internacional Orbis Tertius de Teoría y Crítica Literaria, Universidad Nacional de La Plata, La Plata, Argentina, 2012.

Miller, Richard. African Rhythms in Brazilian Popular Music: Tango Brasileiro, Maxixe and Choro. In: Luso Brazilian Review 48:1 (2011): 6-35. 
Moehn, Frederick. A Carioca Blade Runner, or How Percussionist Marcos Suzano Turned the Brazilian Tambourine into a Drum Kit, and Other Matters of (Politically) Correct Music Making. In: Ethnomusicology 53:2 (2009): 277-307.

Oliven, Ruben. A Parte e O Todo: A Diversidade Cultural No Brasil - Nacão. Petrópolis: Vozes, 1992.

Ramil, Vitor. A estética do frio: conferência de Genebra. Porto Alegre: Satolep, 2004. . A Pontuação da Primavera. São Paulo: Cosac Naify, 2014.

. Pequod. Porto Alegre: L\&PM, 1999.

. Satolep. São Paulo: Cosac Naify, 2008.

Sosa, Marcos Miraballes. Bebeto Alves e Vitor Ramil: Rendimento à Milonga. In: Cadernos do IL 41 (2010): 78-94.

Wrege Rassier, Luciana. A problemática identitária na 'Estética do Frio' de Vitor Ramil. In: Antares 1 (2008): 108-124.

. De Pequod a Satolep: identidades em jogo na obra de Vitor Ramil. In: Estudos de Literatura Brasileira Contemporânea, 32 (2008a): 187-207.

. O universo passa na minha rua. Entrevista com Vitor Ramil, seguida de trechos inéditos de Satolep. In: Quadrant 21 (2004): 209-237. 